\title{
Planktic foraminiferal response to an early Paleocene transient warming event and biostratigraphic implications
}

\author{
André Bornemann $^{1}$ (D) Sofie Jehle ${ }^{2} \cdot$ Friederike Lägel $^{2} \cdot$ Arne Deprez $^{3} \cdot$ Maria Rose Petrizzo $^{4} \cdot$ Robert P. Speijer $^{3}$
}

Received: 24 April 2020 / Accepted: 4 December 2020 / Published online: 22 February 2021

(c) The Author(s) 2021

\begin{abstract}
The Latest Danian Event (LDE, 62.2 Ma) is characterized by global changes in the carbon cycle as indicated by two negative $\delta^{13} \mathrm{C}$ excursions of up to $\sim 1 \%$. These $\delta^{13} \mathrm{C}$ shifts are accompanied by a $2-3{ }^{\circ} \mathrm{C}$ warming of both surface and deep waters based on benthic and planktic foraminiferal $\delta^{18} \mathrm{O}$ measurements, and the LDE has, thus, been considered as a so-called hyperthermal event. The event lasted for $200 \mathrm{kyr}$ and has been identified in various ocean basins and shallow marine settings. Here, we present a compilation of data from three deep-sea cores covering the Pacific, North and South Atlantic oceans as well as a southern Tethyan shelf section to document the response of planktic foraminifera assemblages to ocean warming. In all studied successions, we observe the disappearance of the planktic foraminifer genus Praemurica on a global scale that took place close to the onset of the LDE. Moreover, on the long run, praemuricids were contemporaneously replaced by morozovellids. Both the decline of Praemurica and a temperature increase started between 200 and 260 kyr before the LDE onset and were punctuated by the LDE itself. In this paper, we propose two mechanisms that have controlled the environmental changes associated with this event, (1) increased activity of the North Atlantic Igneous Province acting on long time-scales, and (2) changes of orbital parameters resulting in insolation changes on shorter time-scales.

In contrast to a proposed muted benthic foraminiferal response, the planktic community has been substantially impacted by the LDE as indicated by changes in planktic foraminifera faunas and calcareous nannofossils. Finally, our quantitative and conventional approaches identifying stratigraphically important planktic foraminifera datum levels justify a revision of the upper Danian to lower Selandian planktic foraminifera biozonation.
\end{abstract}

Keywords Paleocene $\cdot$ Latest Danian Event $\cdot$ Planktic foraminifera $\cdot$ Biostratigraphy $\cdot$ Paleoceanography

\section{Introduction}

About 62.2 million years ago, a 200-thousand-year-lasting warming episode has been documented from various oceanic and shallow marine basins over the last decade (e.g., Bornemann et al. 2009; Westerhold et al. 2011; Jehle et al.

André Bornemann

andre.bornemann@bgr.de

1 Bundesanstalt für Geowissenschaften und Rohstoffe, Stilleweg 2, 30655 Hannover, Germany

2 Institut für Geophysik und Geologie, Universität Leipzig, Talstr. 35, 04103 Leipzig, Germany

3 Department of Earth and Environmental Sciences, KU Leuven, Celestijnenlaan 200E, B-3001 Heverlee, Belgium

4 Dipartimento di Scienze Della Terra "Ardito Desio", Università Degli Studi di Milano, Via Mangiagalli 34, 20133 Milano, Italy
2015, 2019; Deprez et al. 2017a, b; Barnet et al., 2019). This event was named "Latest Danian Event" (LDE; Bornemann et al. 2009) and is also known as the "Top C27n Event" (Westerhold et al. 2008, 2011), due to its magnetostratigraphic position. Results from deep-sea sediments document that the LDE is characterized by negative $\delta^{13} \mathrm{C}$ and $\delta^{18} \mathrm{O}$ excursions in benthic and planktic foraminiferal calcite as well as by a drop in sedimentary $\mathrm{CaCO}_{3}$ (Westerhold et al. 2011; Jehle et al. 2015, 2019; Deprez et al. 2017a, b). Oxygen isotope temperature estimates suggest that the entire water column warmed by $2-3{ }^{\circ} \mathrm{C}$ during the LDE (Jehle et al. 2015, 2019). In addition to the known similarities in sedimentological, environmental and biotic responses between the LDE and the "Paleocene-Eocene Thermal Maximum" (PETM), which is the most intensively studied early Cenozoic hyperthermal, as observed on Egyptian shelf successions (e.g., Speijer 2003; Schulte et al. 2013), the documented $\delta^{18} \mathrm{O}$ decrease at all deep-sea sites paralleling the 
negative $\delta^{13} \mathrm{C}$ excursion (CIE) strongly supports the idea that the LDE represents a Paleocene hyperthermal.

Over the last years, numerous studies focused on the identification of the LDE, and some studies investigated the benthic response on shelf sections and in the deep sea (Sprong et al. 2011, 2012, 2013; Alegret et al. 2016; Deprez et al. 2017a, b; Yamaguchi et al. 2017). However, data on openoceanic planktic communities are rather rare so far (Monechi et al. 2013; Jehle et al. 2015, 2019); whereas, more common studies from the Egyptian and Tunisian shelves are often hampered by the lack of an accurate stratigraphic framework. Here, we present a comprehensive overview of planktic foraminiferal assemblage data to assess the marine planktic ecosystem response as well as the paleoceanographic perturbations that are related to the LDE on a supra-regional scale by employing a quantitative approach. This overview is based on two published records from the Pacific and South Atlantic (Jehle et al. 2015, 2019) that are complemented by new data from the North Atlantic and southern Tethyan shelf (Egypt). This combination of well-dated, partly astrochronologically tuned deep-sea sites from different ocean basins (North and South Atlantic, Pacific) and the Tethyan shelf section provides a first general overview of planktic foraminiferal assemblage changes accompanying the LDE.

\section{Materials and methods}

Four sites from the Pacific (Shatsky Rise, ODP Site 1210), the South Atlantic (Walvis Ridge, ODP Site 1262), the North Atlantic (Southeast Newfoundland Ridge, IODP Site U1407), and the southern Tethyan shelf (Egypt, Qreiya 3; Fig. 1) have been studied for stable isotope stratigraphy and relative abundances in planktic foraminiferal assemblages. Stratigraphically, the sampled interval covers the P3a, P3b and P4 planktic foraminiferal Bio(sub)zones over $900 \mathrm{kyr}$ across the LDE (62.2 Ma). Samples from ODP Site 1210 and 1262 used by Jehle et al. $(2015,2019)$ have been reevaluated for rare occurrences of biostratigraphic marker species. Details of all studied sites are summarized in Table 1.

Sediment samples were oven-dried at $40{ }^{\circ} \mathrm{C}$ for at least $48 \mathrm{~h}$ and washed through a $63-\mu \mathrm{m}$-mesh sieve. Planktic foraminifera were identified under a binocular microscope at $50 \times$ magnification following the taxonomic concepts of Berggren and Norris (1997) and Olsson et al. (1999). Faunal data were generated by counting representative splits of at least 300 specimens per sample. For stable isotope analyses on benthic foraminifera, 3-7 specimens of Nuttallides truempyi were taken from the 125-180 $\mu \mathrm{m}$ size-fraction of Sites 1210 and 1262; whereas, bulk-rock samples were used from Site U1407. Samples were reacted with $100 \%$ phosphoric acid at $75{ }^{\circ} \mathrm{C}$ using a Kiel IV online carbonate preparation line connected to a MAT 253 mass spectrometer
(Univ. Leipzig). Specimens of the benthic Pyramidulina were analyzed from Qreiya 3 samples using a Kiel III online carbonate preparation line connected to a ThermoFinnigan 252 mass spectrometer at the Univ. Erlangen. Reproducibility was checked by replicate analysis of laboratory standards and was always better than $\pm 0.1 \% \circ(1 \sigma)$ for both $\delta^{13} \mathrm{C}$ and $\delta^{18} \mathrm{O} . \mathrm{CaCO}_{3}$ values are derived from measurements carried out with an Elementar III (VARIO Corp.) CNS analyzer (Univ. Leipzig; Site 1210) and a LECO CS 230 carbon-sulfur analyzer (BGR, Hannover; Sites 1262 and U1407). Further details are available in Bornemann et al. (2009), Jehle et al. (2015, 2019), Deprez et al. (2017b) and Yamaguchi et al. (2017).

\section{Results and discussion}

\section{Preservation and carbonate dissolution}

Light microscope and scanning electron microscope observations on planktic foraminifera of ODP Sites 1210 and 1262 reveal sparse overgrowth and incipient recrystallization, but an overall moderate to good preservation (Fig. 2). Analyzed planktic foraminifera tests are free from infillings and display a milky appearance. This "frosty" type of preservation is known to cause heavier $\delta^{18} \mathrm{O}$ values, since the added recrystallized calcite carries partly a bottom water isotope signature, resulting in lower temperature estimates than for pristinely preserved tests. $\delta^{13} \mathrm{C}$ is assumed to represent an almost original isotope composition (Pearson et al. 2001; Sexton et al. 2006). For benthic foraminifera, the impact of recrystallization on both isotope species is considered to be minor (Voigt et al. 2016). A detailed discussion of the diagenetic impact on the stable isotope results and the interpretation of assemblage data is given in Jehle et al. $(2015,2019)$.

For North Atlantic IODP Site U1407, the test preservation was usually worse compared to the two other deep-sea sites due to calcite recrystallization and incipient silicification (Van Bael et al. 2016). Therefore, we only used bulkcarbonate samples to identify the LDE-related CIEs. Species-level census data of well-preserved foraminifera from Sites 1210 and 1262 are considered reliable by Jehle et al. $(2015,2019)$; whereas, those of the poorer preserved assemblages from IODP Site U1407 and the Qreiya 3 section are consistent on the generic levels, albeit interpretations on the species level are limited. Thus, for IODP Site 1407 and the Qreiya 3 section only census data on the generic level are presented.

The average $\mathrm{CaCO}_{3}$ content of $84-95 \mathrm{wt} \%$ at ODP Site 1210 is slightly higher than at $1262(68-86 \mathrm{wt} \%)$, with distinct declines of 10-18 wt\% (Fig. 3) contemporary to the two LDE beds. At both sites, the first $\mathrm{CaCO}_{3}$ drop (lower 
Fig. 1 a Present-day map (based on GEBCO data) and (b) paleogeographic map after Seton et al. (2012; $60 \mathrm{Ma})$ showing the positions of the studied sites (large dots) and other locations that are mentioned in the text (small dots). Further details about these sites are given in Table 1. Base map of Fig. 1b has been reprinted from EarthScience Reviews, 113, Seton et al., Global continental and ocean basin reconstructions since $200 \mathrm{Ma}$, Pages 212-270, 2012, with permission from Elsevier
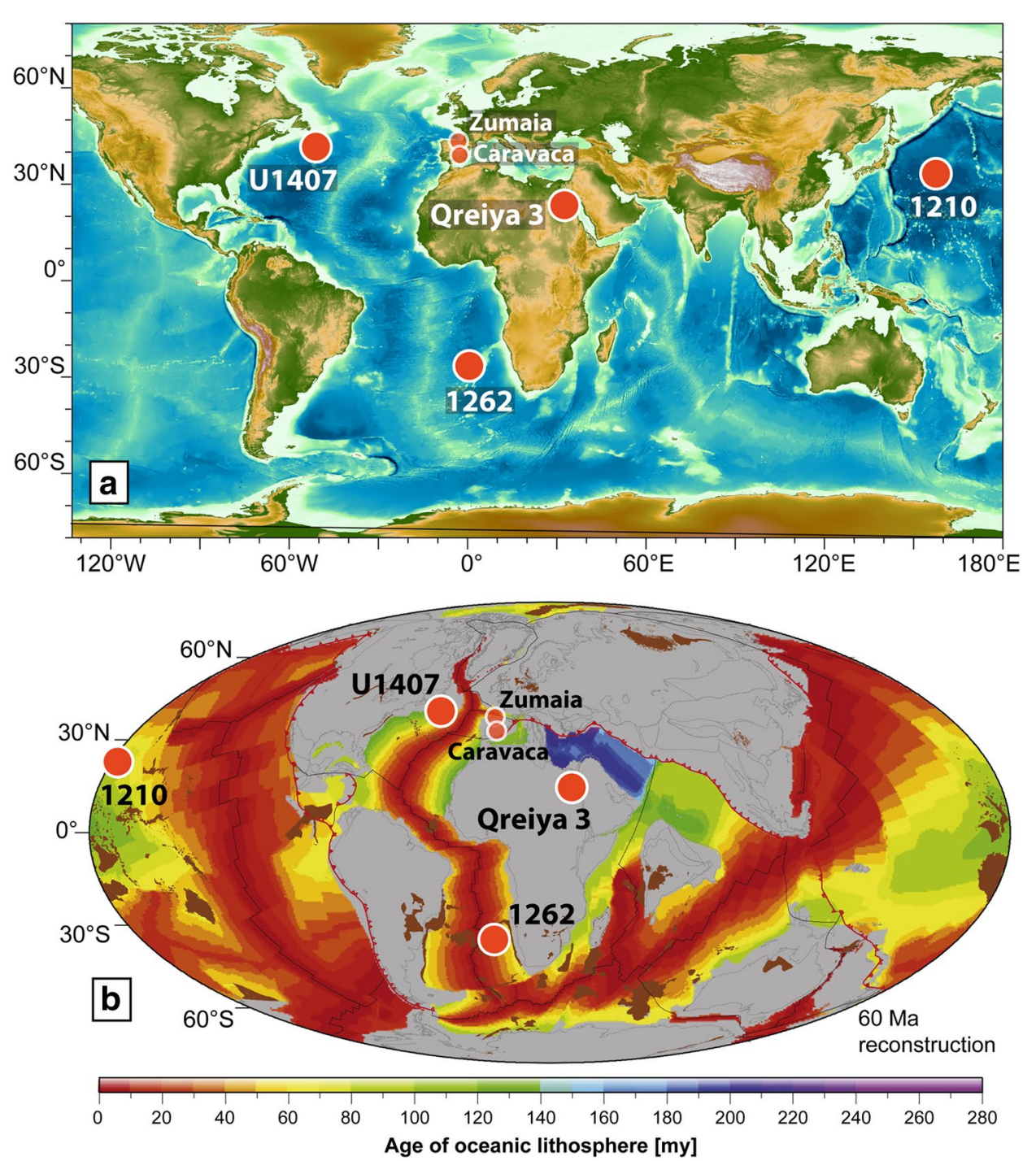

Table 1

\begin{tabular}{|c|c|c|c|c|c|}
\hline & & ODP Site 1210 & ODP Site 1262 & IODP Site U1407 & Qreiya 3 \\
\hline \multicolumn{2}{|c|}{ Geography/basin: } & western Pacific Ocean & eastern South Atlantic & western North Atlantic & Egypt, southern Tethyan shelf \\
\hline \multicolumn{2}{|c|}{ Coordinates: } & $32^{\circ} 13.4123^{\prime} \mathrm{N}, 158^{\circ} 15.5618^{\prime} \mathrm{E}$ & $27^{\circ} 11.150^{\prime} \mathrm{S}, 1^{\circ} 34.620^{\prime} \mathrm{E}$ & $41^{\circ} 25.4994^{\prime} \mathrm{N}, 49^{\circ} 48.7988^{\prime} \mathrm{W}$ & $26^{\circ} 27.702^{\prime} \mathrm{N}, 33^{\circ} 1.905^{\prime} \mathrm{E}$ \\
\hline \multicolumn{2}{|c|}{ Paleo-latitude (62.1 Ma): } & $24.4^{\circ} \mathrm{N}$ & $40.7^{\circ} \mathrm{S}$ & $31.6^{\circ} \mathrm{N}$ & $9.2^{\circ} \mathrm{N}$ \\
\hline \multicolumn{2}{|c|}{ N samples PF: } & 59 & 40 & 16 & 15 \\
\hline \multicolumn{2}{|c|}{$\mathrm{N}$ samples $\delta^{13} \mathrm{C}$ : } & 80 & 90 & 87 & 37 \\
\hline LO Praemurica & \multirow{5}{*}{ 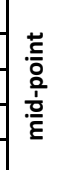 } & $234.16 \mathrm{rmcd} / 62.115 \mathrm{Ma}$ & $195.02 \mathrm{mcd} / 62.125 \mathrm{Ma}$ & $210.5 \mathrm{~m} \mathrm{CCSF}$ & $8.65 \mathrm{~m}$ \\
\hline LCO Praemurica & & $234.36 \mathrm{rmcd} / 62.148 \mathrm{Ma}$ & $195.31 \mathrm{mcd} / 62.149 \mathrm{Ma}$ & $211.18 \mathrm{~m} \mathrm{CCSF}$ & $\mathrm{n} / \mathrm{a}$ \\
\hline decline Praemurica & & $235.35 \mathrm{rmcd} / 62.409 \mathrm{Ma}$ & $196.81 \mathrm{mcd} / 62.359 \mathrm{Ma}$ & $212.31 \mathrm{~m} \mathrm{CCSF}$ & $\mathrm{n} / \mathrm{a}$ \\
\hline FCO Igorina albeari & & $235.94 \mathrm{rmcd} / 62.539 \mathrm{Ma}$ & $196.81 \mathrm{mcd} / 62.359 \mathrm{Ma}$ & $212.31 \mathrm{~m} \mathrm{CCSF}$ & $7.77 \mathrm{~m}$ \\
\hline FO lgorina albeari & & $236.39 \mathrm{rmcd} / 62.715 \mathrm{Ma}$ & $197.69 \mathrm{mcd} / 62.444 \mathrm{Ma}$ & $212.31 \mathrm{~m} \mathrm{CCSF}$ & $7.77 \mathrm{~m}$ \\
\hline
\end{tabular}

$F O$ first occurrence, $F C O$ first consistent occurrence, $L O$ last occurrence, $L C O$ last consistent occurrence, $P F$ planktic foraminifera

Paleolatitude calculation are for 62.1 Ma based on Torsvik et al. (2012) using https://paleolatitude.org/ (van Hinsbergen et al. 2015). Absolute ages are based on the astrochronological age model given by Dinares-Turell et al. (2014, Lascar11 solution) 
Fig. 2 Scanning electron microscope images of selected planktic foraminifera: (a-c) Igorina albeari (a, c: ODP 1210A$23 \mathrm{H}-3,37.5-39 \mathrm{~cm}$; b: ODP 1262B-20H-5, 78-80 cm), (d, e) Morozovella praeangulata (d: ODP 1262B-20H-5, 78-80 cm; e: ODP-1210A-23-2, 127.5$129 \mathrm{~cm})$; (f, g) Praemurica uncinata (both ODP 1210A23H-3, 80-81.5 cm); scale $\mathrm{bar}=100 \mu \mathrm{m}$

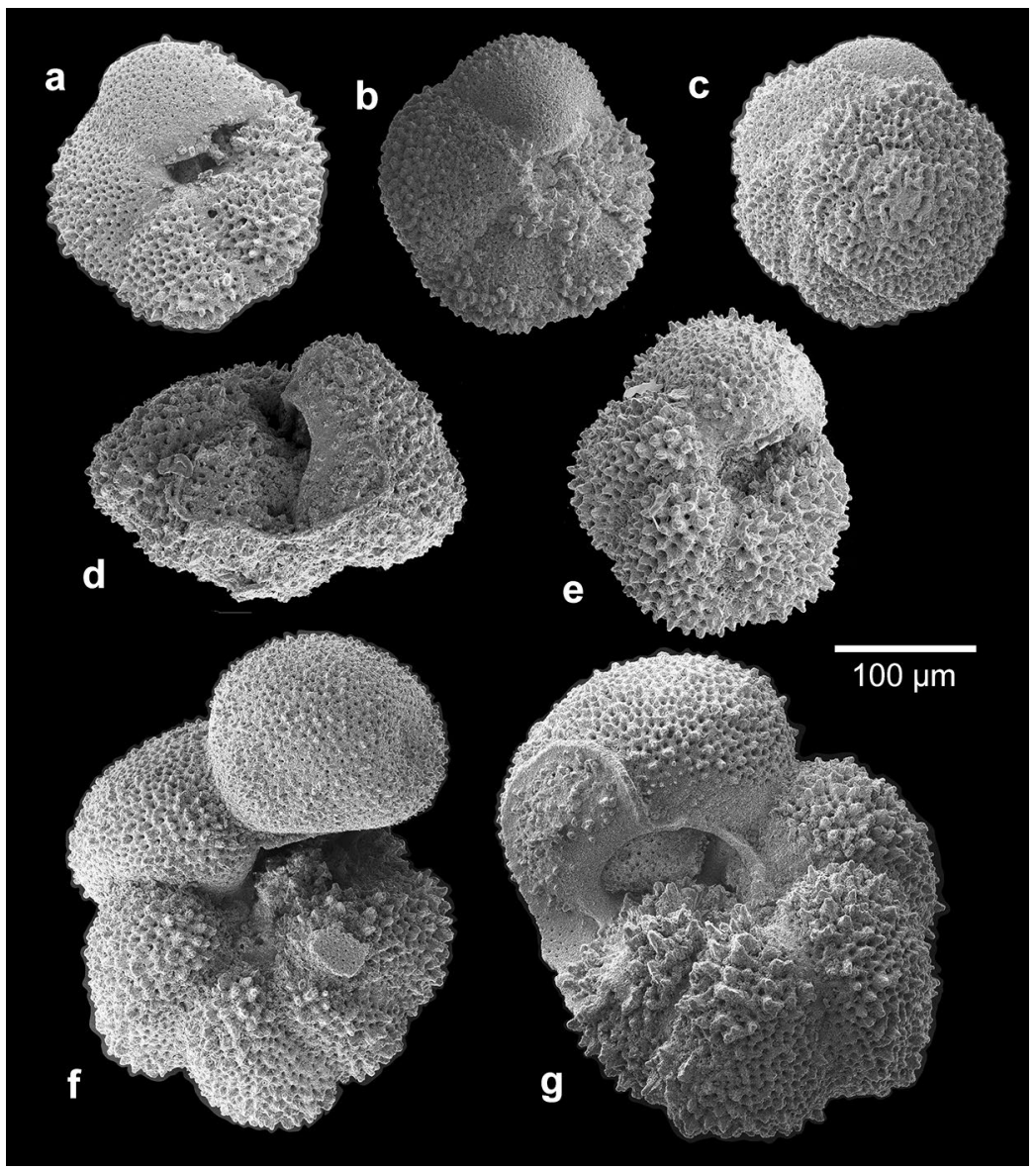

LDE bed $=$ LDE1) has been attributed to carbonate dissolution due to lysocline shallowing likely as a consequence of enhanced $\mathrm{CO}_{2}$ input to the ocean-atmosphere system similar to the PETM, albeit less severe (Jehle et al. 2015, 2019). The origin of the second, minor $\mathrm{CaCO}_{3}$ drop in the upper LDE bed (=LDE2) is less clear and may have been caused by a combination of dissolution and dilution. Jehle et al. (2015, 2019) document a very muted signal of dissolution proxies such as coarse fraction and fragmentation data.

$\mathrm{CaCO}_{3}$ patterns in the North Atlantic and in Egypt are different from the two key sites discussed above. At North Atlantic IODP Site U1407, carbonate drops from background values of $\sim 65 \mathrm{wt} \%$ by up to $15 \mathrm{wt} \%$ below the event beds (Fig. 3). At this site, the $\mathrm{CaCO}_{3}$ drop seems to have resulted from incipient silicification and not from dissolution (Van Bael et al. 2016), similar to the PETM at the same site (Penman et al. 2019). Relative abundances of planktic foraminifera are constantly high at $~ 99 \%$, and neither planktic nor benthic foraminifera show short-term decreases of abundance in the study interval (Deprez 2017).

On the Egyptian shelf at the Qreiya 3 section, the LDE is also associated with carbonate-poor sediments (Fig. 3). In this case the LDE sediments are, similar to the PETM at the same section, represented by a black shale bed with a directly underlying dissolution interval (Schulte et al. 2013). This dissolution interval is possibly caused by downward migration of a redox front with low-pH pore waters caused by the organic load and pyrite alteration above (Sprong et al. 2012), a phenomenon that is well known as the "burning down" effect from Quaternary sapropels in the Mediterranean Sea (e.g., Higgs et al. 1994).

\section{Carbon and oxygen isotope anomalies}

Besides the significant decrease in $\mathrm{CaCO}_{3}$, the two LDE beds are associated with negative $\delta^{13} \mathrm{C}$ and $\delta^{18} \mathrm{O}$ shifts in benthic and planktic foraminifera. Bornemann et al. (2009) observed a negative CIE of up to $2 \%$ in benthic foraminifera at various shelf sections in Egypt. In subsequent studies, it was shown that this CIE occurs also in benthic and planktic foraminiferal calcite from deep-sea sediments, albeit at a lower amplitude of 0.7-0.9\%o (Westerhold et al. 2011; Jehle et al. 2015, 2019; Deprez et al. 2017a, b; Barnet et al. 2019). So far, the CIE has been documented for the Pacific (ODP Sites 1209, 1210: Westerhold et al. 2011; Jehle et al. 2015), North Atlantic (Site U1407: Yamaguchi et al. 2017; Zumaia: Schmitz et. al. 1998; Dinares-Turell et al. 2014) and 
ODP Site 1262

(Walvis Ridge, South Atlantic)

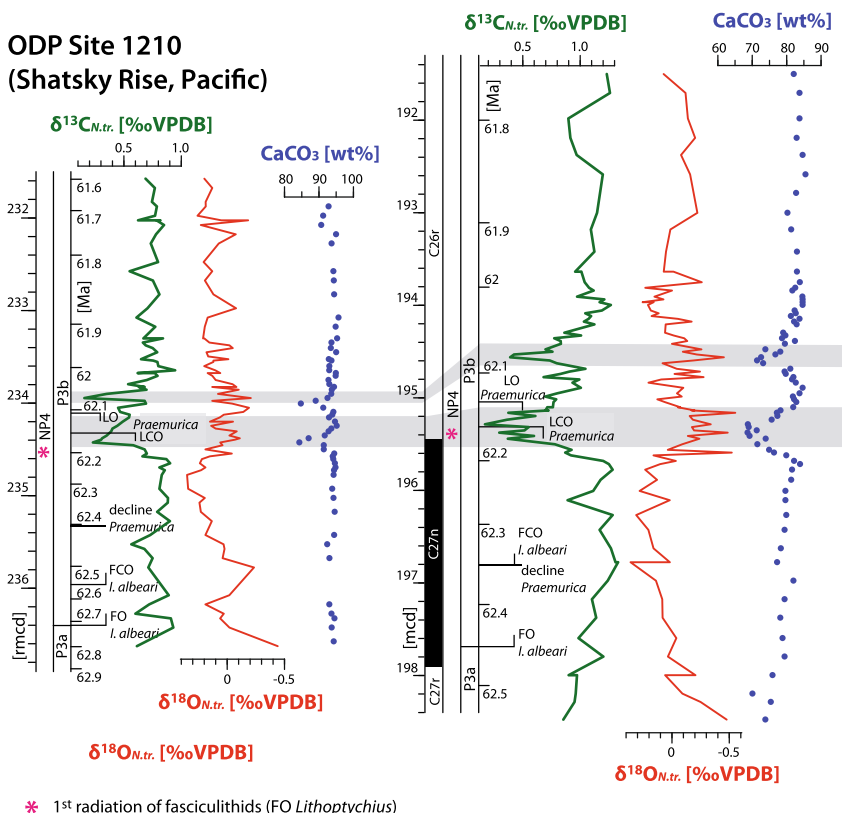

* $1^{\text {st }}$ radiation of fasciculithids (FO Lithoptychius)

Fig. 3 Geochemical and biostratigraphic data of the four sites. $\delta^{13} \mathrm{C}$ chemostratigraphy shows negative carbon isotope excursions at the identified onset of the LDE1 (62.2 Ma) at all studied sites. For the three deep-sea sites a second excursion (LDE2) is apparent. $\delta^{18} \mathrm{O}$ shows at all deep-sea sites, a shift to more negative values during the LDE interval. No $\delta^{18} \mathrm{O}$ data are shown for the Qreiya $3 \mathrm{sec}-$ tion, because $\delta^{18} \mathrm{O}$ is not primarily controlled by temperature on the relatively shallow shelf as discussed in Bornemann et al. (2009). At all sites $\mathrm{CaCO}_{3}$ contents drop during the LDE beds. Data shown are partly published by Bornemann et al. (2009), Jehle et al. (2015,

South Atlantic (ODP Site 1262: Deprez et al. 2017a; Barnet et al. 2019) as well as from the Tethyan shelf successions in Egypt (Bornemann et al. 2009) and Spain (Caravaca, Alegret et al. 2016) (Fig. 3). Thus, the negative CIE seems to be a common feature of the LDE. At all deep-sea sites, the LDE shows a double-negative CIE at 100-kyr spacing similar to other Eocene hyperthermal pairs. Further, more pronounced events such as H1(ETM2 = Eocene Thermal Maximum 2, 54.0 Ma)-H2, I1-I2 or LDE, typically coincide with eccentricity maxima (Westerhold et al. 2011; DinaresTurell et al. 2014; Littler et al. 2014). In contrast to the deep sea, all onshore successions studied so far consist of only one unequivocally identifiable negative CIE for the LDE (Bornemann et al. 2009; Dinares-Turell et al. 2014; Alegret et al., 2016). A likely reason might be that the usually less well-resolved outcrop records did simply not cover the peak values of the second CIE, or alternatively, the low magnitude of the LDE2 CIE has been further diminished by homogenization processes such as enhanced bioturbation.

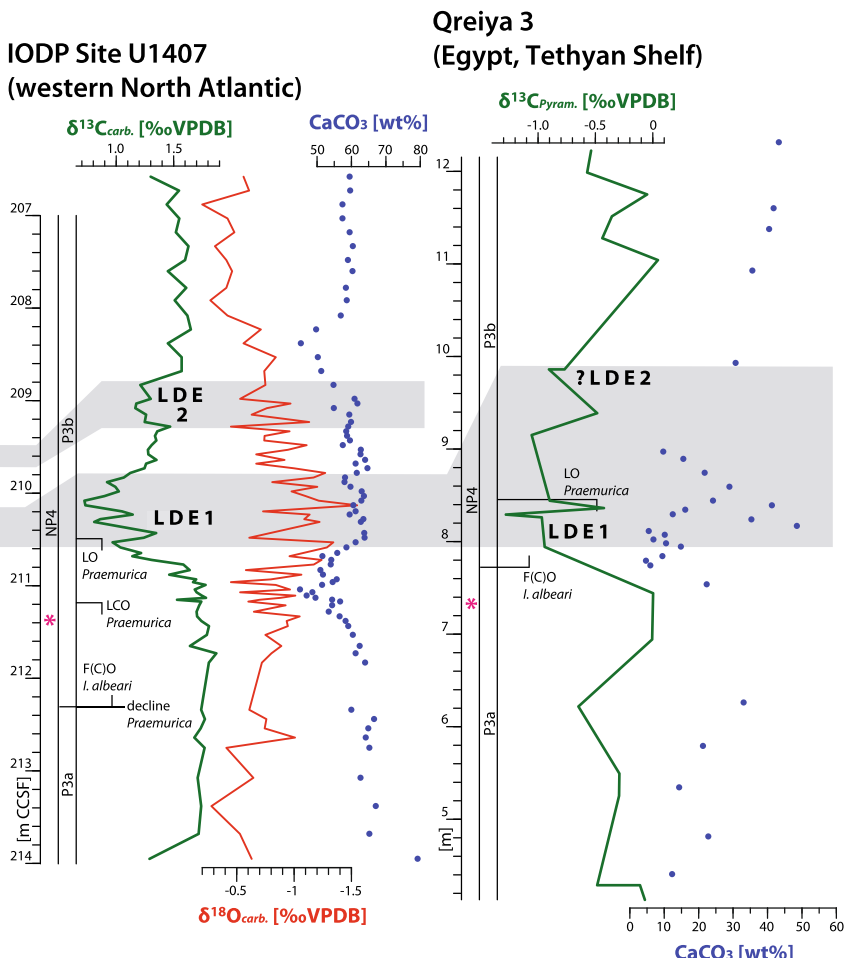

2019), Deprez et al. (2017a, b), Schulte et al. (2013) and Yamaguchi et al. (2017). Asterisks mark the stratigraphic position of the 1st radiation of fasciculithids at the studied sites (1262: Monechi et al., 2013; Qreiya 3: Sprong et al., 2009; U1407: Yamaguchi et al., 2017). Absolute ages of ODP Sites 1210 and 1262 are based on the astrochronology of Dinares-Turell et al. (2014, Lascar11 solution). Magnetostratigraphy of ODP Site 1262 according to Bowles (2006). FO first occurrence, $F C O$ first consistent occurrence, $L O$ last occurrence, $L C O$ last consistent occurrence

Ocean warming of up to $3{ }^{\circ} \mathrm{C}$ during the LDE as indicated by benthic and planktic foraminiferal oxygen isotope data (e.g., Jehle et al. 2015, 2019) is associated with two negative carbon isotope excursions. Therefore, the LDE can be considered to represent the first hyperthermal of the Cenozoic. Other candidates such as the Dan-C2 event (65.6 Ma) lack apparent ocean warming and a low magnitude of carbon cycle changes (Barnet et al. 2019; Fig. 4). The orbital heartbeat on the short-eccentricity frequency band continues throughout the early Paleocene in the Westerhold et al. (2011, 2020) and Barnet et al. (2019) records, but none of the preceding events are as large as the LDE. Paired excursions of $\delta^{13} \mathrm{C}$ and $\delta^{18} \mathrm{O}$ do occur before the LDE but are smaller in magnitude than the LDE. However, even when the most negative $\delta^{18} \mathrm{O}$ values largely correlate with the negative CIEs of the LDE, a continuous $\delta^{18} \mathrm{O}$ decline of background values already commences $\sim 200 \mathrm{kyr}$ before the LDE onset as dated at Shatsky Rise and Walvis Ridge (Fig. 3).

The LDE shows a striking similarity in magnitude of benthic foraminiferal $\delta^{13} \mathrm{C}$ and $\delta^{18} \mathrm{O}$ changes to the 
H1(ETM2)-H2 pair (Fig. 4). Further, Deprez et al. (2017a) have demonstrated that the LDE and other early Eocene hyperthermal pairs share a similar relationship of the $\delta^{13} \mathrm{C}-\delta^{18} \mathrm{O}$ gradient. Thus, similar causes have been inferred for these events (Deprez et al. 2017a). Similarities in the $\delta^{13} \mathrm{C}$ composition of the carbon source and orbital configuration point to carbon input from a common ${ }^{12} \mathrm{C}$-enriched carbon reservoir causing the double-peaked CIEs of the LDE and the early Eocene hyperthermals. However, the exact nature of the reduced carbon is still under discussion. Several theoretical release mechanisms have been proposed in the past, such as volcanogenic outgassing, destabilization of gas hydrates due to deep-sea circulation changes or warming, peat oxidation by longer dry seasons or destabilization of permafrost during eccentricity maxima (e.g., Zachos et al. 2010; DeConto et al. 2012). Based on the occurrence of hyperthermal pairs, Barnet et al. (2019) propose that the carbon reservoir has not been fully emptied during the first excursion, which has a larger amplitude, because of the existence of a second smaller event about 100 kyr later. They further speculate that such a short time period between carbon isotope excursions argues for a dynamic carbon reservoir as the main source for orbitally paced hyperthermals, allowing for a quick replenishment, and against a reservoir with long refueling times as considered for biogenic methane hydrates.
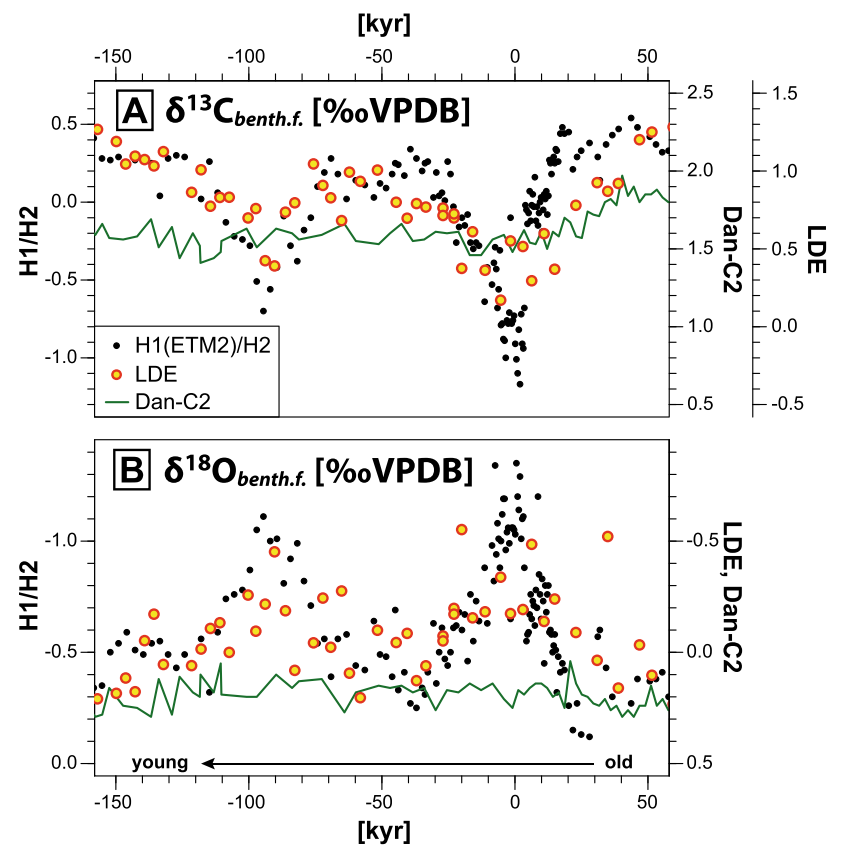

Fig. 4 Comparison of benthic foraminiferal (a) $\delta^{13} \mathrm{C}$ and (b) $\delta^{18} \mathrm{O}$ across three potential warming events during the early Paleogene at Walvis Ridge ODP Site 1262: Dan-C2 Event (65.6 Ma), H1(ETM2) and $\mathrm{H} 2$ (54.0 Ma) and Latest Danian Event (LDE, 62.2 Ma) (data: Eocene-Littler et al. (2014) and Stap et al. (2010); Dan-C2-Barnet et al. 2017, 2019; LDE: this study). Age model for all events follows Barnet et al. (2019)

\section{Biotic response}

During the study interval, planktic foraminiferal assemblages of the mid-latitudinal Sites 1262 and U1407 are dominated by the mesotrophic, subsurface taxa Subbotina and Parasubbotina; whereas warm, oligotrophic surface waters Morozovella species are dominant in the Pacific (Site 1210) and on the Egyptian shelf (Fig. 5). At all sites, planktic foraminiferal assemblages show a continuous shift through time with increased relative abundances of Morozovella, specifically M. praeangulata and M. angulata, as well as Igorina (all thermophile, photosymbiotic surface-dwellers) during the study interval. This observed long-term transition is also in line with the hypothesis that Morozovella (prae-)angulata potentially evolved from Praemurica uncinata (e.g., Kelly et al. 1999). Further, all sites show a largely synchronous disappearance of Praemurica at the base of the LDE, paralleled by a gradual long-term increase of Morozovella abundance. Specifically, at Site 1262, an apparent increase of Morozovella and Igorina within the two LDE beds has been observed in both relative (Fig. 5) and absolute abundances indicating surface-water warming (see data in Jehle et al. 2019). Our observations imply that there is not only a shortterm specific response to the LDE itself, but also a transition in the total faunal composition on the long run (Fig. 5).

Results from the two astrochronologically-tuned Sites 1210 and 1262 indicate that faunal changes such as the demise of the Praemurica genus started about $200 \mathrm{kyr}$ before the LDE comparable to the pre-LDE increase of both ocean temperature (Fig. 3) and surface ocean stratification at Pacific Site 1210 (Jehle et al. 2015). An early decline in Praemurica abundance well below the LDE is also apparent at Site U1407 (Fig. 5). Thus, a similar extinction pattern of Praemurica has been observed at all three deep-sea sites studied showing first a relative abundance decline about $200 \mathrm{kyr}$ before the LDE and a final disappearance of this taxon during LDE1. In addition to the deep-sea records, new census data from Qreiya 3 section (Egypt) and published data from Tunisia, Jordan and other Egyptian sites (Guasti 2005; Guasti et al. 2006) as well as Wombat Plateau (Indian Ocean, Quillévéré et al. 2002) also show the disappearance of this taxon close to the presumed position of the LDE. In combination with the 1 st radiation of the calcareous nannofossil group fasciculithids (sensu Monechi et al. 2013), which has also been observed directly before the first LDE bed at all four sites (Figs. 3, 5). Our observations suggest that the environmental changes associated with the LDE passed a certain threshold resulting in a persistent change of the surface ocean biota. Similar to the invention of photosymbiosis in planktic foraminifera (e.g., Norris et al. 1996; Birch et al. 2012), the appearance of fasciculithids has been interpreted as a response to enhanced oceanic oligotrophy (Fuqua et al. 1998; Aubry et al. 2012). The relatively rapid 


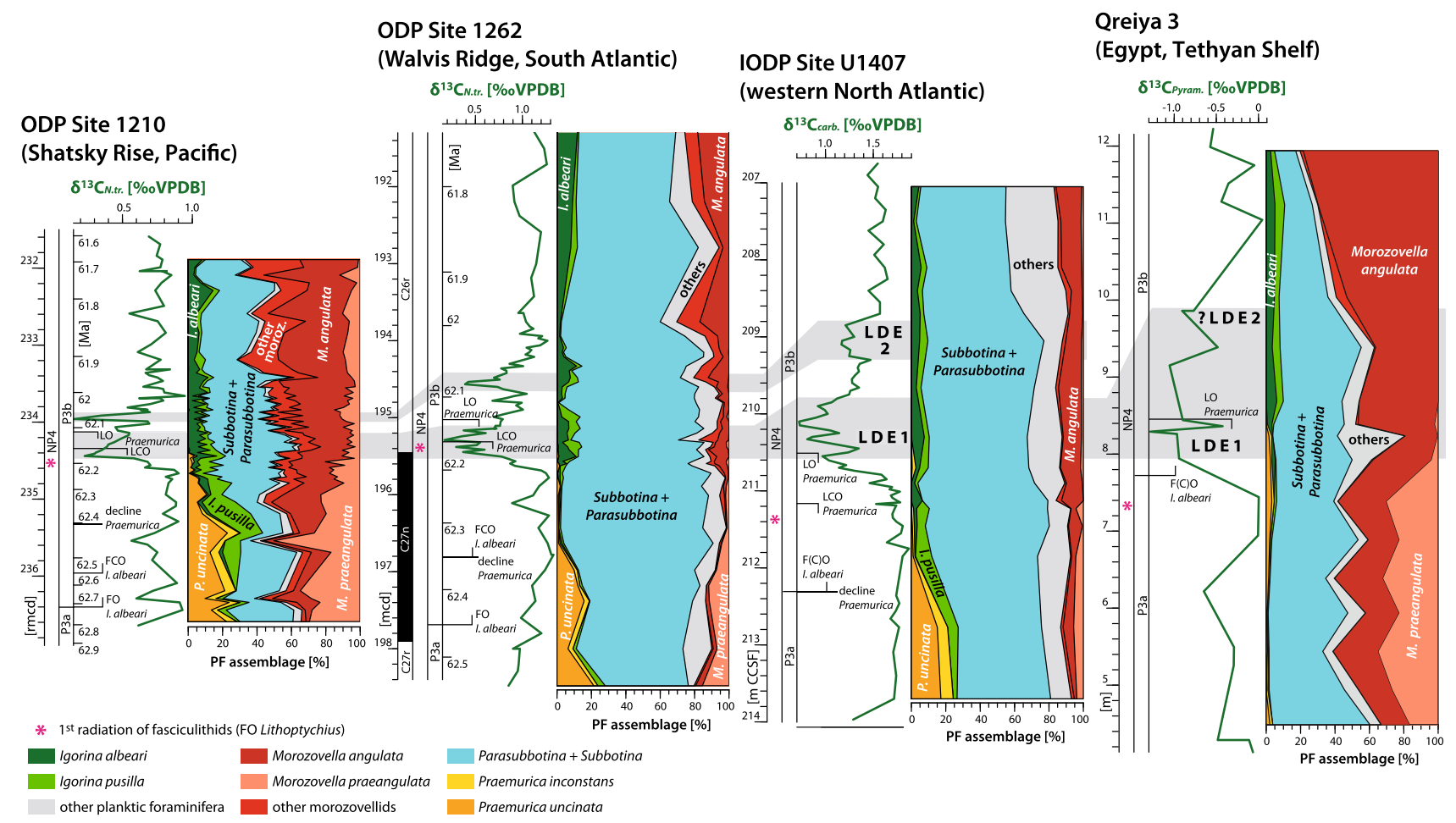

Fig. 5 Chemo- and biostratigraphy including abundance data of the major planktic foraminifera taxa and groupings, specifically those taxa discussed herein: Igorina albeari, Praemurica uncinata and $P$. inconstans as well as Morozovella praeangulata and M. angulata. $\delta^{13} \mathrm{C}$ chemostratigraphy shows negative carbon isotope excursions at the identified onset of the LDE1 (62.15 Ma) at all studied sites [Shatsky Rise ODP Site 1210 and Walvis Ridge ODP Site 1262, Newfoundland IODP Site U1407, Qreiya 3]. For the three deep-sea sites also a second excursion (LDE2) is apparent. Data shown are partly published by Bornemann et al. (2009), Jehle et al. (2015), Deprez

warming during LDE1 and linked changes in the upper ocean structure, such as enhanced surface-water stratification in the central Pacific as evidenced by stable isotope gradients and biotic data (Jehle et al. 2015), may have led to the evolution of the fasciculithid genus Lithoptychius and contributed to the extinction of the Praemurica lineage.

The well-developed changes in the planktic community contrast with the muted response for the benthic deep-sea environment which is not consistently responding to the LDE. Benthic assemblages (foraminifera, ostracods) display a long-term shift maybe due to an adaptation to the change of the planktic biota and the resulting nutrient flux to the seafloor (Deprez et al. 2017a, b; Yamaguchi et al. 2017). The benthic response to the LDE is also different from observations of early Eocene hyperthermals (H1(ETM2)-H2, and the PETM; D'haenens et al. 2012, 2014; Arreguin-Rodriguez et al. 2018), which show a clear response to the warming events in the benthic faunas. This discrepancy has been explained by a cooler early Paleocene background bottom et al. (2017a, b) and Yamaguchi et al. (2017). Asterisks mark the stratigraphic position of the 1st radiation of fasciculithids at the studied sites (1262: Monechi et al. 2013; Qreiya 3: Sprong et al. 2009; U1407: Yamaguchi et al., 2017). Absolute ages of ODP Sites 1210 and 1262 are based on the astrochronology of Dinares-Turell et al. (2014, Lascar11 solution). Magnetostratigraphy of ODP Site 1262 according to Bowles (2006). Abbreviations: FO first occurrence, FCO first consistent occurrence, $L O$ last occurrence, $L C O$ last consistent occurrence

water temperature and the lack of threshold-related circulation changes. In addition, benthic communities were well adapted to higher temperatures, as the LDE is superimposed on an early Paleocene cooling trend, in contrast to the warming trend during the early Eocene (Deprez et al. 2017a). Besides the planktic response to the LDE, also continental records reveal a major turnover of land mammals supporting the idea of global environmental changes during this interval (Clyde et al. 2008).

\section{Possible causes of the Latest Danian Event}

The cause of the LDE is still under discussion. Our highly resolved records allow to disentangle faunal responses on different time-scales, and we propose that continuous warming commencing roughly $200 \mathrm{kyr}$ before the onset of the LDE is likely to have been controlled by tectonics. It is intriguing that plume-related volcanic activities of the North Atlantic Igneous Province started at $\sim 62 \mathrm{Ma}$ on both 
sides of Greenland including the British Isles, Baffin Island, Labrador Sea as well as eastern and western Greenland (e.g., Chalmers and Pulvertaft 2001; Larsen et al. 2016; Steinberger et al. 2018). For the onset of sea-floor spreading in the Labrador Sea, Chalmers and Pulvertaft (2001) proposed an age within magnetochron $\mathrm{C} 27 \mathrm{n}$, i.e., right before the LDE. This makes volcanic $\mathrm{CO}_{2}$ input likely as a potential cause for the observed long-term changes, specifically for the rise in background temperature during the study interval.

Large-amplitude changes in relative abundances of biota and temperature at the LDE are linked with maxima of short-eccentricity cycles (100 kyr) during which precession cycles are amplified causing enhanced seasonal insolation changes (Westerhold et al. 2008; Barnet et al. 2019), which in turn might have amplified warming through a greenhouse feedback. This warming eventually seems to have passed a certain threshold for a number of taxa to become less abundant or even extinct. Alternatively, orbital pacing might have triggered changes in ocean ventilation, leading to oxidation of dissolved organic matter and the release of ocean stored $\mathrm{CO}_{2}$ as proposed for minor transient Eocene warming events (Sexton et al. 2011). These events have a similar magnitude as the LDE deep-sea records and show also a 100-kyr spacing, but are much shorter in duration (40 kyr) than the more pronounced Paleogene hyperthermals including the LDE, ETM2 and others.

\section{Biostratigraphic implications}

The combined approach of high-resolution $\delta^{13} \mathrm{C}$ stratigraphy, magnetostratigraphy and astrochronological tuning (Westerhold et al. 2008; Dinares-Turell et al. 2014; Barnet et al. 2019) allows to reevaluate the synchronicity and reliability of biostratigraphic marker species. Our quantitative approach enables us not only to identify first occurrences (FOs) and last occurrences (LOs), but also to distinguish between FOs and first consistent occurrences (FCOs), and LOs and last consistent occurrences (LCOs), respectively. Evolutionary first appearances of planktic microfossils are often followed by sporadic occurrences, before occurring continuously in detectable numbers. Correspondingly, extinctions are introduced by declining abundances and sporadic occurrences. This is the reason why the first or last consistent occurrence has been considered to represent a more accurate stratigraphic marker than simple first or last occurrences (Agnini et al. 2014), which are more easily missed. The quantitative approach makes the stratigraphic position of a marker also less prone to reworking and contamination. In addition, significant changes in relative abundances such as the decline of Praemurica species about 200 kyr before the LDE are recognized.

In earlier studies, the LDE was positioned stratigraphically within planktic foraminiferal Subzone P3b close to the
FO of Igorina albeari (Westerhold et al. 2008; Sprong et al. 2009), which defines the base of P3b (e.g., Berggren and Pearson 2005; Wade et al. 2011). However, our results show that the FOs of I. albeari at the studied sites are well below the LDE (Site 1210: 62.72 Ma; Site 1262: 62.44 Ma), and are, thus, diachronous by several 100 kyr (Fig. 6). A somewhat more consistent picture becomes apparent when the FCO of I. albeari is considered (Site 1210: $62.54 \mathrm{Ma}$; Site 1262: 62.36 Ma). This suggests that the FO I. albeari is a suboptimal marker for high-resolution biostratigraphy on a submillion-year scale. Furthermore, the taxonomic concepts behind this taxon are rather ambiguous (Sprong et al. 2009; Soldan et al. 2011; Arenillas 2012). The herein applied taxon concept follows the widely accepted work by Olsson et al. (1999), which includes Igorina laevigata (sensu Soldan et al. 2011). Soldan et al. (2011) proposed an earlier FO of I. laevigata than I. albeari, which might also contribute to explain the observed diachrony with previously published records. Finally, I. albeari is rather rare below the LDE (Jehle et al. 2015) and might, thus, have been potentially overlooked in some studies.

In contrast, the LOs of Praemurica specimens take place slightly after or within the later part of LDE1 at Sites 1210 and 1262, whereas the LCO of this taxon seems to coincide with the onset of the LDE1 CIE in both astrochronologically calibrated sites (Table 1, Fig. 5). Accordingly, the extinction of this genus provides a more reliable chronostratigraphic marker than I. albeari. However, preference should be given to the LCO of Praemurica rather than to the LO to avoid biases due to reworking and sporadic occurrences. Differences in the position of biostratigraphic events between the well-resolved ODP Sites 1210 and 1262 on the one hand and U1407 (and Qreiya 3) on the other hand might be partly due to lower resolution of the latter record. In addition, also the " 1 st radiation of fasciculithids" (FO Lithoptychius) calcareous nannofossil event is useful to approximate biostratigraphically the LDE (Figs. 3, 5; Schmitz et al. 2011; Monechi et al. 2013).

The general acceptance that the LDE occurs within planktic foraminifera Subzone P3b and right on top of magnetochron $\mathrm{C} 27 \mathrm{n}$ at the two astrochronologically tuned key Sites 1210 and 1262 is significantly different from the mid-Paleocene biozonations (Berggren et al. 1995; Berggren and Pearson 2005; Wade et al. 2011). In these zonations, the position of the $\mathrm{P} 3 \mathrm{a} / \mathrm{P} 3 \mathrm{~b}$ boundary is about $1 \mathrm{Myr}$ younger than the top of $\mathrm{C} 27 \mathrm{n}$ (Fig. 6), and thus, a revision of the planktic foraminifera zonation of the upper Danian to lowermost Selandian interval is required. Further additional bioevents are desirable to increase the resolution of the expanded P3b planktic foraminiferal Subzone, which is according to our results about $1.5 \mathrm{Myr}$ long. Finally, as a further consequence, the FOs of Praemurica uncinata and Morozovella angulata, both taxa occurring consistently 


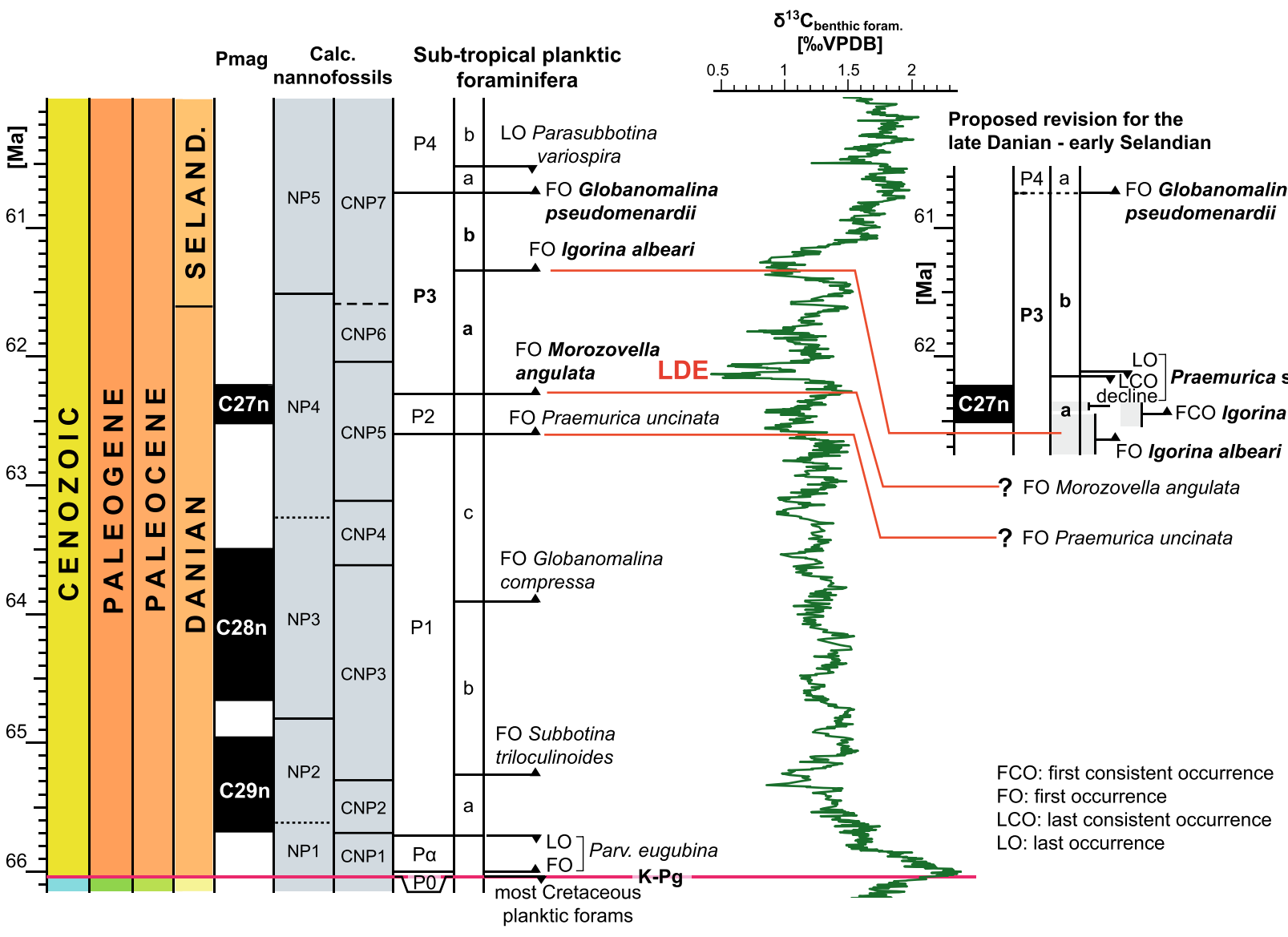

Fig. 6 Comparison of late Danian planktic foraminifera standard biozonation according to Geological Timescale 2016 (Ogg et al. 2016; left panel, TSCreator v7.4), $\delta^{13} \mathrm{C}$ chemostratigraphy (ODP Site 1262; Barnet et al. 2019) and findings of this study (right panel). Grayish bars on the right indicate stratigraphic uncertainties based on astro-

from the base of the studied cores upwards, are much older than proposed by the standard zonation scheme (Fig. 6).

\section{Conclusions}

In all studied successions, the disappearance of the planktic foraminifer genus Praemurica takes place at the onset of, or slightly within, the LDE, indicating that this extinction event is synchronous on an almost global scale. On the long run, morozovellids increase in relative abundance at the expanse of praemuricids. The decline of Praemurica and the observed temperature increase started between 200 and $260 \mathrm{kyr}$ before the LDE and are punctuated by the LDE. Furthermore, a LDE warming is supported by an increase of thermophile taxa (morozovellids and igorinids) specifically at Site 1262. The observed long-term change in fauna and temperature is herein related to the volcanic activity in chronological ages for Sites 1210 and 1262 (Table 1). Calcareous nannofossil zonation refers to Martini (1971) - NP zonation, and Agnini et al. (2014) - CNP zonation. Planktic foraminifera stratigraphy refers to Wade et al. (2011)

the North Atlantic Igneous Province; whereas, the transient warming and the faunal response at the LDE might be triggered either by the extreme orbital configuration during this event and/or the input of additional $\mathrm{CO}_{2}$ from other sources.

Finally, we observe that the FO of Igorina albeari is diachronous by $300 \mathrm{kyr}$ between ocean basins and occurs much earlier than suggested by standard planktic foraminiferal biozonations; whereas, the stratigraphic position of the LCO, and to a lesser extent the LO, of Praemurica is more consistent among the sites studied. This leads us to conclude (1) that a quantitative biostratigraphic approach is often more reliable than simple FOs or LOs and (2) that there is a need for a revision of the planktic foraminifera biozonation of the upper Danian-lower Selandian.

Supplementary Information The online version contains supplementary material available at https://doi.org/10.1007/s00531-020-01972-z. 
Acknowledgments This research used samples and data provided by the International Ocean Discovery Program (IODP). IODP is sponsored by the USA National Science Foundation (NSF) and participating countries. Financial support was provided to $\mathrm{AB}$ and $\mathrm{SJ}$ by DFG grants BO2505/8-1 and EH89/20-2 and by the KU Leuven Research Fund to RPS. MRP acknowledge funds from the University of Milan. S. Krüger is thanked for stable isotope measurements and F. Wolter (both Univ. Leipzig) for picking samples from the Qreiya 3 section. We further thank James Barnet and Dick Kroon for their insightful and constructive comments.

Funding Open Access funding enabled and organized by Projekt DEAL.

Open Access This article is licensed under a Creative Commons Attribution 4.0 International License, which permits use, sharing, adaptation, distribution and reproduction in any medium or format, as long as you give appropriate credit to the original author(s) and the source, provide a link to the Creative Commons licence, and indicate if changes were made. The images or other third party material in this article are included in the article's Creative Commons licence, unless indicated otherwise in a credit line to the material. If material is not included in the article's Creative Commons licence and your intended use is not permitted by statutory regulation or exceeds the permitted use, you will need to obtain permission directly from the copyright holder. To view a copy of this licence, visit http://creativecommons.org/licenses/by/4.0/.

\section{References}

Agnini C, Fornaciari E, Raffi I, Catanzariti R, Pälike H, Backman J, Rio D (2014) Biozonation and biochronology of Paleogene calcareous nannofossils from low and middle latitudes. Newsl Strat 47:131-181

Alegret L, Ortiz S, Arreguín-Rodríguez GJ, Monechi S, Millán I, Molina E (2016) Microfossil turnover across the uppermost Danian at Caravaca, Spain: paleoenvironmental inferences and identification of the latest Danian event. Palaeogeogr Palaeoclimatol Palaeoecol 463:45-59

Arenillas I (2012) Patterns of spatio-temporal distribution as criteria for the separation of planktic foraminiferal species across the Danian-Selandian transition in Spain. Acta Palaeontol Polon 57:401-422

Arreguin-Rodriguez GJ, Thomas E, Dhaenens S, Speijer RP, Alegret L (2018) Early Eocene deep-sea benthic foraminiferal faunas: recovery from the paleocene eocene thermal maximum extinction in a greenhouse world. PLoS ONE. https://doi.org/10.1371/ journal.pone.0193167

Aubry MP, Rodriguez O, Bord D, Godfrey L, Schmitz B, Knox RWO (2012) The first radiation of the fasciculiths: morphologic adaptations of the coccolithophores to oligotrophy. Austrian J Earth Sci 105:29-38

Barnet JSK, Littler K, Kroon D, Leng MJ, Westerhold T, Röhl U, Zachos JC (2017) A new high-resolution chronology for the late maastrichtian warming event: establishing robust temporal links with the onset of deccan volcanism. Geology 46:147-150

Barnet JSK, Littler K, Westerhold T, Kroon D, Leng MJ, Bailey I, Röhl U, Zachos JC (2019) A high-fidelity benthic stable isotope record of late cretaceous-early eocene climate change and carboncycling. Paleoceanogr Paleoclimatol 34:672-691

Berggren WA, Norris RD (1997) Biostratigraphy, phylogeny and systematics of Paleocene trochospiral planktic foraminifera. Micropaleontol 43:119
Berggren WA, Pearson PN (2005) A revised tropical to subtropical Paleogene planktonic foraminiferal zonation. J Foraminif Res 35:279-298

Berggren WA, Kent DV, Swisher Iii CC, Aubry MP (1995) A revised cenozoic geochronology and chronostratigraphy. SEPM Spec Publ $54: 129-212$

Birch HS, Coxall HK, Pearson PN (2012) Evolutionary ecology of Early Paleocene planktonic foraminifera: size, depth habitat and symbiosis. Paleobiol 38:374-390

Bornemann A, Schulte P, Sprong J, Steurbaut E, Youssef M, Speijer RP (2009) Latest Danian carbon isotope anomaly and associated environmental change in the southern Tethys (Nile Basin, Egypt). J Geol Soc 166:1135-1142

Bowles J (2006) Data report: revised magnetostratigraphy and magnetic mineralogy of sediments from Walvis Ridge, Leg 208. ODP Scientif Rep. https://doi.org/10.2973/odp.proc.sr.208.206.2006

Chalmers JA, Pulvertaft TCR (2001) Development of the continental margins of the Labrador Sea: a review. Geol Soc London Spec Publ 187:77-105

Clyde WC, Tong Y, Snell KE, Bowen GJ, Ting S, Koch PL, Li Q, Wang Y, Meng J (2008) An integrated stratigraphic record from the Paleocene of the Chijiang Basin, Jiangxi Province (China): Implications for mammalian turnover and Asian block rotations. Earth Planet Sci Lett 269:554-564

DeConto RM, Galeotti S, Pagani M, Tracy D, Schaefer K, Zhang T, Pollard D, Beerling DJ (2012) Past extreme warming events linked to massive carbon release from thawing permafrost. Nature 484:87-91

Deprez A (2017) Response of deep-sea biota to rapid global warming during the early Paleocene. $\mathrm{PhD}$ thesis, KU Leuven

Deprez A, Jehle S, Bornemann A, Speijer RP (2017a) Differential response at the seafloor during Palaeocene and Eocene ocean warming events at Walvis Ridge, Atlantic Ocean (ODP Site 1262). Terra Nova 29:71-76

Deprez A, Jehle S, Bornemann A, Speijer RP (2017b) Pronounced biotic and environmental change across the latest Danian warming event (LDE) at Shatsky Rise, Pacific Ocean (ODP Site 1210). Mar Micropaleontol 137:31-45

Dhaenens S, Bornemann A, Stassen P, Speijer RP (2012) Multiple early eocene benthic foraminiferal assemblage and $\delta 13 \mathrm{C}$ fluctuations at DSDP Site 401 (Bay of Biscay - NE Atlantic). Mar Micropaleontol 88-89:15-35

Dhaenens S, Bornemann A, Claeys P, Röhl U, Steurbaut E, Speijer RP (2014) A transient deep-sea circulation switch during eocene thermal maximum 2. Paleoceanogr 29:370-388

Dinares-Turell J, Westerhold T, Pujalte V, Röhl U, Kroon D (2014) Astronomical calibration of the Danian stage (Early Paleocene) revisited: settling chronologies of sedimentary records across the Atlantic and Pacific Oceans. Earth Planet Sci Lett 405:119-131

Fuqua LM, Bralower TJ, Arthur MA, Patzkowsky ME (2008) Evolution of calcareous nannoplankton and the recovery of marine food webs after the Cretaceous-Paleocene mass extinction. Palaios 23:185-194

Guasti E (2005) Early Paleogene environmental turnover in the southern Tethys as recorded by foraminiferal and organic-walled dinoflagellate cyst assemblages. University of Bremen, Bremen

Guasti E, Speijer RP, Brinkhuis H, Smit J, Steurbaut E (2006) Paleoenvironmental change at the Danian-Selandian transition in Tunisia: foraminifera, organic-walled dinoflagellate cyst and calcareous nannofossil records. Mar Micropaleontol 59:210-229

Higgs NC, Thomson J, Wilson TRS, Croudace IW (1994) Modification and complete removal of eastern mediterranean sapropels by postdepositional oxidation. Geology 22:423-426

Huber BT, Petrizzo MR, Young JR, Falzoni F, Gilardoni SE, Bown PR, Wade BS (2016) Pforams@ mikrotax. Micropaleontology 62(6):429-438 
Jehle S, Bornemann A, Deprez A, Speijer RP (2015) The Impact of the Latest danian event on planktic foraminiferal faunas at ODP Site 1210 (Shatsky Rise, Pacific Ocean). PLoS ONE 10(11):e0141644

Jehle S, Bornemann A, Lägel AF, Deprez A, Speijer RP (2019) Paleoceanographic changes across the Latest Danian Event in the South Atlantic Ocean and planktic foraminiferal response. Palaeogeogr Palaeoclimatol Palaeoecol 525:1-13

Kelly DC, Arnold AJ, Parker WC (1999) The influence of heterochrony on the stratigraphic occurrence of Morozovella angulata. J Foraminif Res 29:58-68

Larsen LM, Pedersen AK, Tegner C, Duncan RA, Hald N, Larsen JG (2016) Age of Tertiary volcanic rocks on the West Greenland continental margin: volcanic evolution and event correlation to other parts of the North Atlantic Igneous Province. Geol Mag 153:487-511

Littler K, Röhl U, Westerhold T, Zachos JC (2014) A high-resolution benthic stable-isotope record for the South Atlantic: Implications for orbital-scale changes in Late Paleocene-Early Eocene climate and carbon cycling. Earth Planet Sci Lett 401:18-30

Monechi S, Reale V, Bernaola G, Balestra B (2013) The Danian/Selandian boundary at Site 1262 (South Atlantic) and in the Tethyan region: biomagnetostratigraphy, evolutionary trends in fasciculiths and environmental effects of the Latest Danian Event. Mar Micropaleontol 98:28-40

Norris RD (1996) Symbiosis as an evolutionary innovation in the radiation of Paleocene planktic foraminifera. Paleobiol 22:461-480

Ogg JG, Ogg G, Gradstein F (2016) A concise geologic time scale. Elsevier, Amsterdam

Olsson RK, Hemleben C, Berggren WA, Huber BT (1999) Atlas of Paleocene Planktonic Foraminifera. Smithsonian Inst Press, Washington, DC

Pearson PN, Ditchfield PW, Singano J, Harcourt-Brown KG, Nicholas CJ, Olsson RK, Shackleton NJ, Hall MA (2001) Warm tropical sea surface temperatures in the Late Cretaceous and Eocene epochs. Nature 413:481-487

Penman DE, Keller A, Dhaenens S, Turner SK, Hull PM (2019) Atlantic deep-sea cherts associated with Eocene hyperthermal events. Paleoceanogr Paleoclimatol 34:287-299

Quillévéré F, Aubry MP, Norris RD, Berggren WA (2002) Paleocene oceanography of the eastern subtropical Indian Ocean - An integrated magnetobiostratigraphic and stable isotope study of ODP Hole 761B (Wombat Plateau). Palaeogeogr Palaeoclimatol Palaeoecol 184:371-405

Schmitz B, Molina E, von Salis K (1998) The Zumaya section in Spain: a possible global stratotype section for the Selandian and Thanetian stages. Newsl Stratigr 36:35-42

Schmitz B, Pujalte V, Molina E, Monechi S, Orue-Etxebarria X, Speijer RP, Alegret L, Apellaniz E, Arenillas I, Aubry MP, Baceta JI, Berggren WA, Bernaola G, Caballero F, Clemmensen A, Dinares-Turell J, Dupuis C, Heilmann-Clausen C, Orus AH, Knox R, Martin-Rubio M, Ortiz S, Payros A, Petrizzo MR, Von Salis K, Sprong J, Steurbaut E, Thomsen E (2011) The global stratotype sections and points for the bases of the selandian (Middle Paleocene) and Thanetian (Upper Paleocene) stages at Zumaia, Spain. Episodes 34:220-243

Schulte P, Schwark L, Stassen P, Kouwenhoven TJ, Bornemann A, Speijer RP (2013) Black shale formation during the Latest danian event and the paleocene-eocene thermal maximum in central Egypt: two of a kind? Palaeogeogr Palaeoclimatol Palaeoecol 371:9-25

Seton M, Müller RD, Zahirovic S, Gaina C, Torsvik T, Shephard G, Talsma A, Gurnis M, Turner M, Maus S, Chandler M (2012) Global Continental and Ocean Basin Reconstructions since 200Ma. Earth Sci Rev 113:212-270
Sexton PF, Wilson PA, Pearson PN (2006) Microstructural and geochemical perspectives on planktic foraminiferal preservation: 'Glassy" versus 'Frosty". Geochem Geophys Geosys 7:1-6. https ://doi.org/10.1029/2006GC001291

Sexton PF, Norris RD, Wilson PA, Pälike H, Westerhold T, Röhl U, Bolton CT, Gibbs S (2011) Eocene global warming events driven by ventilation of oceanic dissolved organic carbon. Nature 471:349-353

Soldan DM, Petrizzo MR, Premoli-Silva I, Cau A (2011) Phylogenetic relationships and evolutionary history of the Paleogene genus Igorina through parsimony analysis. J Foraminif Res 41:260-284

Speijer RP (2003) Danian-Selandian sea-level change and biotic excursion on the southern Tethyan margin (Egypt). Geol Soc Am Spec Pap 369:275-290

Sprong J, Speijer RP, Steurbaut E (2009) Biostratigraphy of the Danian/ Selandian transition in the southern tethys special reference to the lowest occurrence of planktic foraminifera Igorina albeari. Geol Acta 7:63-77

Sprong J, Youssef MA, Bornemann A, Schulte P, Steurbaut E, Stassen P, Kouwenhoven TJ, Speijer RP (2011) A multi-proxy record of the latest danian event at gebel qreiya, Eastern Desert. Egypt J Micropalaeontol 30:167-182

Sprong J, Kouwenhoven TJ, Bornemann A, Schulte P, Stassen P, Steurbaut E, Youssef M, Speijer RP (2012) Characterization of the Latest Danian Event by means of benthic foraminiferal assemblages along a depth transect at the southern Tethyan margin (Nile Basin, Egypt). Mar Micropaleontol 86-87:15-31

Sprong J, Kouwenhoven TJ, Bornemann A, Dupuis C, Speijer RP, Stassen P, Steurbaut E (2013) In search of the Latest Danian Event in a paleobathymetric transect off Kasserine Island, north-central Tunisia. Palaeogeogr Palaeoclimatol Palaeoecol 379-380:1-16

Stap L, Lourens LJ, Thomas E, Sluijs A, Bohaty SM, Zachos JC (2010) High-resolution deep-sea carbon and oxygen isotope records of Eocene Thermal Maximum 2 and H2. Geology 38:607-610

Steinberger B, Bredow E, Lebedev S, Schaeffer A, Torsvik TH (2018) Widespread volcanism in the Greenland-North Atlantic region explained by the Iceland plume. Nature Geosci 12:61-68

Torsvik TH, Van der Voo R, Preeden U, Mac Niocaill C, Steinberger B, Doubrovine PV, van Hinsbergen DJJ, Domeier M, Gaina C, Tohver E, Meert JG, McCausland PJA, Cocks LRM (2012) Phanerozoic polar wander, palaeogeography and dynamics. Earth Sci Rev 114:325-368

Van Bael R, Deprez A, Stassen P, Bornemann A, Speijer RP (2016) Taphonomic impact of ultrasonic treatment on foraminifera from a deep-sea carbonate ooze. J Micropalaeontol 35:229-231

van Hinsbergen DJ, de Groot LV, van Schaik SJ, Spakman W, Bijl PK, Sluijs A, Langereis CG, Brinkhuis H (2015) A paleolatitude calculator for paleoclimate studies. PLoS ONE 10:e0126946

Voigt J, Hathorne EC, Frank M, Holbourn A (2016) Minimal influence of recrystallization on middle Miocene benthic foraminiferal stable isotope stratigraphy in the eastern equatorial Pacific. Paleoceanography 31:98-114

Wade BS, Pearson PN, Berggren WA, Pälike H (2011) Review and revision of Cenozoic tropical planktonic foraminiferal biostratigraphy and calibration to the geomagnetic polarity and astronomical time scale. Earth Sci Rev 104:111-142

Westerhold T, Röhl U, Raffi I, Fornaciari E, Monechi S, Reale V, Bowles J, Evans HF (2008) Astronomical calibration of the Paleocene time. Palaeogeogr Palaeoclimatol Palaeoecol 257:377-403

Westerhold T, Röhl U, Donner B, McCarren HK, Zachos JC (2011) A complete high-resolution Paleocene benthic stable isotope record for the central Pacific ODP Site. Paleoceanogr. https://doi. org/10.1029/2010PA002092

Westerhold T, Marwan N, Drury AJ, Liebrand D, Agnini C, Anagnostou E, Barnet JSK, Bohaty SM, De Vleeschouwer D, Florindo F, 
Frederichs T, Hodell DA, Holbourn AE, Kroon D, Lauretano V, Littler K, Lourens LJ, Lyle M, Pälike H, Röhl U, Tian J, Wilkens RH, Wilson PA, Zachos JC (2020) An astronomically dated record of Earth's climate and its predictability over the last 66 million years. Science 369:1383-1387

Yamaguchi T, Bornemann A, Matsui H, Nishi H (2017) Latest Cretaceous/Paleocene deep-sea ostracode fauna at IODP Site U1407 (western North Atlantic) with special reference to the Cretaceous/ Paleogene boundary and the Latest Danian Event. Mar Micropaleontol 135:32-44

Zachos JC, McCarren H, Murphy B, Röhl U, Westerhold T (2010) Tempo and scale of late Paleocene and early Eocene carbon isotope cycles: Implications for the origin of hyperthermals. Earth Planet Sci Lett 299:242-249 